\title{
ハロゲン原子導入による タンパク質の構造安定化メカニズムの解明
}

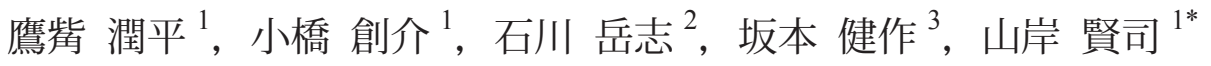 \\ ${ }^{1}$ 日本大学工学部生命応用化学科, $\overline{7} 963-8642$ 福島県郡山市田村町徳定字中河原 1 \\ ${ }^{2}$ 長崎大学 医歯薬学総合研究科, $=852-8523$ 長崎県長崎市坂本2-12-4 \\ 3 (独)理化学研究所, $=230-0045$ 神奈川県横浜市鶴見区未広町1-7-22 \\ *e-mail:yamagisi@chem.ce.nihon-u.ac.jp
}

(Received: November 26, 2014; Accepted for publication: December 12, 2014; Online publication: December 31, 2014)

We carried out $a b$ initio fragment molecular orbital calculations for wild-type and halogenated glutathione S-transferase (GST) at the MP2/6-31G** level. To elucidate the mechanism of structural stability of the halogenated protein, we calculated the interaction energies for all residue pairs in GST by using inter-fragment interaction energy analysis based on the fragment molecular orbital method. We were able to evaluate electrostatic and van der Waals dispersion interaction energies separately and explicitly. Differences in interaction energies of each residue pair between the two structures were interpreted as the effect of halogenation. The results show that the local interaction around halogen atoms was enhanced. The enhanced interaction effects of $\mathrm{Cl}$ and $\mathrm{Br}$ were stronger than those of $\mathrm{F}$ and $\mathrm{I}$.

キーワード: FMO, Ab initio MO, Protein stability, Interaction energy, Halogenation

\section{1 はじめに}

グルタチオンS-トランスフェラーゼ(Glutathione Stransferase；GST)を構成している特定のチロシンを，ハ ロゲン原子をただ一つ導入したハロゲン化チロシンに置 き換えると，タンパク質全体の耐熱性が著しく向上する ことを見いだした。 なぜ，わずか数個のハロゲン原子の 導入が, タンパク質全体の耐熱性を向上させるのか, そ の詳細な分子メカニズムは明らかではない.

本研究は, ハロゲン原子の導入がタンパク質内の相互 作用をどのように変化させるのか, 局所的な相互作用変 化, および全体的な相互作用変化の 2 つの視点から解析 し, ハロゲン原子の導入によるタンパク質の構造安定化 メカニズムについて明らかとすることを目的とした。特 に，本論文ではタンパク質の相互作用が，導入するハ口 ゲン原子の違いによりどのように変化するか網羅的に解 析した。

\section{2 方法}

分子内相互作用の解析には, フラグメント分子軌道 (FMO) 法 [1] 基づくフラグメント間の相互作用エネル

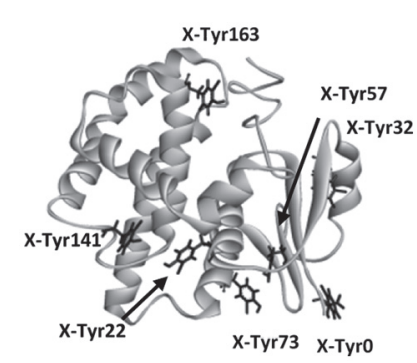

Figure 1. Crystal structure of halogenated glutathione S-transferase. The positions of halogenated tyrosine are depicted.

ギー (IFIE)の解析を用いた，FMO計算では，GSTは1ア ミノ酸残基単位でフラグメントに分割した. ハロゲン化 したチロシン，およびLeu23は，さらに主鎖と側鎖に分 割した。計算レベルはMP2/6-31G**とし，ハロゲン原子 のみ 6-311G**を用い, PAICS [2]を用いて実行した。解 析の対象としたハロゲン化GSTは，Tyr0, 22, 32, 57, 73, 141，163をハロゲン化したGSTとし，ウェット実験によ り最も耐熱性が上昇したものである，WT-GST，および 


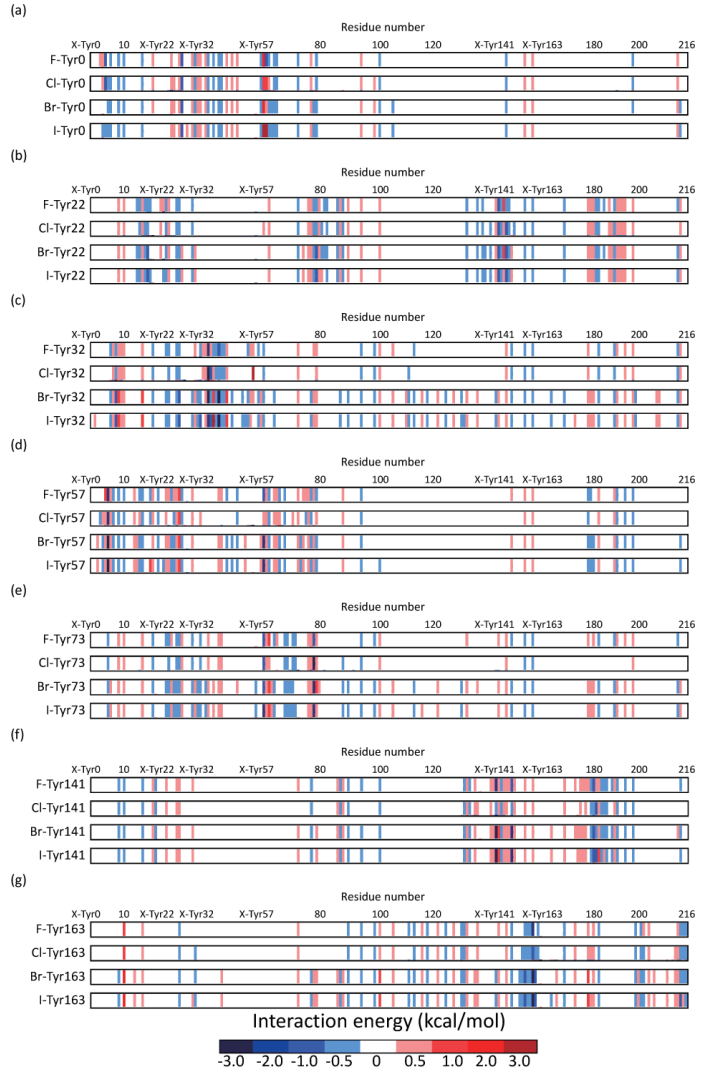

Figure 2. Maps representing the interaction energies between residues and halogenated tyrosine positions (a) 0 , (b) 22, (c) 32, (d) 57, (e) 73, (f) 141, (g) 163.

ハロゲン化GSTの構造はX線の結晶構造を基に作成し た.

\section{3 結果と考察}

ハロゲン化されたGSTに対してFMO計算を行い，す べてのアミノ酸残基ペアの相互作用エネルギーを算出 した。導入したハロゲン原子がタンパク質全体に与え る影響を考察するため, ハロゲン化チロシンとすべての アミノ酸との相互作用エネルギーを色分けして示した (Figure 2).

次に，WT-GST とハロゲン化GST で同じ残基ペアの相 互作用エネルギーを比較し，その差をハロゲン原子の効 果と解釈した. Table 1 には，ハロゲン化チロシンと強く 相互作用を形成し, 強いハロゲンの効果が表れたアミノ
Table 1. Differences in inter-fragment interaction energies of each residue pair between wild-type and halogenated GST. ${ }^{\text {a }}$

\begin{tabular}{|c|c|c|c|c|c|}
\hline $\begin{array}{c}\text { halogenated } \\
\text { tyrosine }\end{array}$ & residue & $\mathrm{F}^{\mathrm{b}}$ & $\mathrm{Cl}^{\circ}$ & $\mathrm{Br}^{\mathrm{d}}$ & $\mathrm{I}^{\mathrm{e}}$ \\
\hline \multirow[t]{3}{*}{ X-Tyr0 } & PRO2 & -0.39 & 0.27 & -0.15 & 0.25 \\
\hline & ILE3 & 1.29 & -1.26 & -1.48 & 0.46 \\
\hline & ILE58 & 0.57 & -0.73 & -0.78 & 0.83 \\
\hline \multirow[t]{4}{*}{ X-Tyr22 } & LEU19 & 0.79 & -0.83 & -1.02 & 1.03 \\
\hline & MET80 & 0.09 & -0.35 & -0.12 & -0.73 \\
\hline & HIS146 & 1.08 & -1.32 & -1.44 & 1.48 \\
\hline & VAL147 & 0.42 & -0.82 & -0.46 & 0.48 \\
\hline \multirow[t]{3}{*}{ X-Tyr32 } & LYS39 & 2.35 & -4.20 & -3.06 & 2.22 \\
\hline & TRP40 & -0.79 & -1.89 & -0.72 & 1.75 \\
\hline & LYSS3 & 185 & -0.14 & -3.55 & 3.27 \\
\hline \multirow{6}{*}{ X-Tyr57 } & PRO2 & -0.01 & 0.29 & -0.23 & 0.22 \\
\hline & LEU4 & 2.11 & -2.29 & -3.01 & 3.01 \\
\hline & LEU20 & 0.32 & -0.44 & 0.02 & -1.25 \\
\hline & LYS26 & 0.27 & -0.10 & -0.47 & 0.50 \\
\hline & TYR27 & -0.31 & -0.73 & -0.38 & 0.49 \\
\hline & ILE70 & -0.01 & 0.49 & -0.03 & 0.06 \\
\hline \multirow[t]{2}{*}{ X-Tyr73 } & ASP59 & 1.47 & -1.24 & -1.99 & 2.25 \\
\hline & LYS77 & 1.23 & -5.59 & -2.09 & 2.65 \\
\hline \multirow[t]{5}{*}{ X-Tyr141 } & VAL147 & 0.16 & -0.48 & -0.65 & 0.94 \\
\hline & ASP151 & 1.99 & -0.88 & -2.67 & 2.65 \\
\hline & ARG181 & 1.28 & -0.82 & -1.96 & 1.29 \\
\hline & ILE182 & -0.74 & -1.06 & -0.83 & 1.78 \\
\hline & ILE 185 & 0.57 & -0.67. & -0.27 & -0.65 \\
\hline \multirow[t]{3}{*}{$x-\operatorname{Tyr} 163$} & TRP200 & -0.16 & -0.64 & -0.15 & 0.50 \\
\hline & PRO215 & 0.78 & -0.71 & -0.67 & -0.46 \\
\hline & PRO216 & 0.27 & -0.17 & -0.76 & 0.95 \\
\hline
\end{tabular}

a. Energies are in kcal/mol. b. Fluorinated GST. c. Chlorinated GST. d. Brominated GST. e. Iodinated GST.

酸残基を抜粋して示した。その結果，ハロゲン原子の効 果は, 塩素原子，および臬素原子は高く，フッ素原子， およびヨウ素原子は小さい傾向が得られた.

\section{4 まとめ}

ハロゲン原子の導入による GSTの構造安定化のメカ ニズムを明らかとするため，ハロゲン化 GSTに対して FMO 計算を行い，GSTを構成するすべての残基ペアの 相互作用エネルギーを算出した。 ハロゲン原子を導入す ることにより，ハロゲン原子周辺の局所的な相互作用は 強化されることが分かった，その効果は，塩素原子，臭 素原子では強く, フッ素原子, ヨウ素原子では小さい傾 向が得られた。

本研究は, 文部科学省私立大学戦略的研究基盤形成支 援事業（平成26年〜平成 30 年), および日本大学工学部 研究費の支援により実施された。

\section{参考文献}

[1] K. Kitaura, et al., Chem. Phys. Lett., 312, 319 (1999). [CrossRef]

[2] T. Ishikawa, T. Ishikura, K. Kuwata, J. Comput. Chem., 30, 2594 (2009). [Medline] [CrossRef] 